\title{
Yaratıcı Drama Dersinin Üniversite Öğrencilerinin Benlik Algısı Üzerine Etkisi
}

\author{
Serap ANTEPLi ${ }^{1} \quad$ Şehnaz CEYLAN ${ }^{2}$
}

\begin{abstract}
$\ddot{O ̈ z e t}$
Bu çalışma, yaratıcı drama dersinin üniversite öğrencilerinin benlik algısı üzerine etkisini incelemek amacılla yapılmıştır. Bu çalışmanın örneklemini, Gazi Üniversitesi Mesleki Ĕ̌itim Fakültesi Çocuk Gelişimi Ĕgitimi Öğretmenliği Programına devam eden 85 ikinci sınıf ögrencisi oluşturmuştur. Veri toplamak amacıyla, Kişisel Bilgi Formu ve Sosyal Karşılaştırma Ölçeği (SKÖ) kullanılmıştır. Toplanan veriler "Wilcoxon Işaretli Stralar Testi" ve "T-Testi" ile analiz edilmiştir. Araştırma sonuçlarına göre, yaratıcı drama ĕgitimi alan ögrencilerin Sosyal Karşılaştırma Ölçeğinden aldıkları deney öncesi ve sonrası puanları arasında anlamlı bir fark olduğunu göstermektedir ( $<.000)$. Yaratıcı drama eğitimi alan ögrencilerin en son bitirdiği okul türüne göre ön test-son test puanları arasında ise anlamlı bir fark olmadı̆̆ bulunmuştur ( $p>$.005).
\end{abstract}

Anahtar Sözcükler: Yaratıcı drama, benlik algısı, çocuk gelişimi eğitimi

\begin{abstract}
This study has been carried out to investigate the effect of creative drama course on the sense of self of university students. The sampling of the study consisted of 85 second year students attending Gazi University, Faculty of Vocational Education, Child Development Education teaching program. In order to collect data, Personal Information Form and Social Comparison Scale (SCS) have been used. The collected data were analyzed with "Wilcoxon Signed Rank Test" and " $t$-test". Depending on the results of the research, a significant difference has been found between the pre-test and post test scores of the students taking the course of creative drama education from the Social Comparison Scale $(p<.000)$. However, no significant difference has been found between the pre and post test scores depending on the latest school the students had taken the course of creative drama education graduated ( $p>.005)$.
\end{abstract}

Keywords: Creative drama, sense of self, child development education

\section{Giriş}

Yaratıcı drama, eğitim ve öğretimde geleneksel yöntemlere göre daha yeni bir oluşum olmasının yanında, etkisi ve uygulanması bakımından birçok olumluluğu da içinde barındırmaktadır. Ezbere dayalı bir eğitim sisteminde birey, bilgiyi arama ve paylaşma firsatı bulamamaktadır. Bu anlamda yaratıcı drama; konu merkezli, ezberci ve yapılandırılmış eğitim anlayışına karşı güçlü bir alternatiftir. Bu nedenle yaratıcı drama, tüm eğitim kademelerinde sıklıkla kullanılması gereken önemli bir yöntemdir. Ayrıca, yaratıcı 
dramanın etkili bir öğrenme yolu olarak, en önemli özelliği, bilişsel, duyuşsal, sosyal ve devinişsel yetilerle bütünleşmiş olmasıdır. Eğitimde, yaparak yaşayarak ve duyu organlarının olabildiğince fazla kullanabilme önemli bir ilkedir. Yaratıcı drama ile geliştirilen bilgi, beceri ve davranış değişiklikleri bireyin yaşama bakışını etkilemesi yönünden son derece önemlidir. Bu da öğrenmede kalıcılığ1 arttırmaktadır (Güven, 2006:141; Adıgüzel, 2006a:8; Can Yaşar ve Ömeroğlu, 2005:168).

Eğitimde yaratıcı dramanın etkililiği birçok eğitimci tarafından vurgulanmıştır. Dorothy Heathcote, dramanın eğitimde ve yaşantılara dayalı öğrenmede etkisini göstermiştir. Ayrıca, dramanın öğrenme için etkin bir yöntem olduğuna inanmış, dramayı "Yaşamın Pratiği”" olarak açıklamıştır. Winifred Ward, yaratıcı dramanın bir eğitim aracı ve yöntemi olduğunu vurgulamıştır. Brian Way, yaratıcı dramayla insanın gelişimi üzerine odaklanmıştır. Drama’nın kişiliğin gelişmesinde rol oynayan doğal bir oyun olduğunu vurgulamıştır. Neil McCaslin, dramayı sadece okuldaki konuların öğretilmesi amaçlı değil, hayal gücünün, bağımsız düşünmenin, iletişim becerilerinin, problem çözme becerilerinin, sosyal farkındalığın ve duygusal gelişimin desteklenmesinde kullanmıştır. Norman'a göre ise; drama kişinin evrensel, toplumsal, etik ve soyut kavramları anlamlandırmasıdır (Akt. San, 2002:65; Akt. Adıgüzel, 2006b:32; Akt. Min Lin,1999:30).

Yaratıcı drama etkinliklerine özellikle erken çocukluk döneminde yer verilmesi, çocuğun aktif kılınmasını sağlayarak, sosyal-duygusal, bilişsel, dil ve psiko-motor gelişimlerini desteklemektedir. Çocukların gelişimini desteklemede aileden sonra gelen en önemli kişi okul öncesi öğretmenidir. $\mathrm{Bu}$ nedenle, okul öncesinde yaratıcı dramaya karşı olumlu görüşlere sahip olan öğretmen adaylarının ileride, eğitim programlarında okul öncesinde drama eğitimine yer vermesi çocukların tüm gelişimlerini destekleyerek bilgiye daha kolay ulaşmalarını sağlayacaktır. Gelişmeye açık etkin bir eğitimci öğrencilerin duygularına değer verir, onların olumlu benlik kavramı geliştirmelerine yardımcı olur (Kara ve Çam, 2007:146).

Benlik, yaşantılar sonucu gelişen edinilmiş bir yapı olarak tanımlanmaktadır. Kişiliğin temelinde bulunan ve birey için çok önemli olan algı, duygu, düşüncelerin bütünüdür. Benlik, kişilerarası bir araç olarak hem kişilerarası iletişimi hem de bireyin kendisini biçimlendirebilmektedir. Kişinin kendini nası1 gördüğü, kendine nasıl değer biçtiğini anlatır. Kişinin, kim olduğu konusundaki düşüncelerinin ve kendisi hakkındaki değerlendirmelerin tümüdür. Bağımsız ve düzen içinde bir varlık olması gereken benlik, bireyin kendi bedenine ve bedeninin fonksiyonlarına iyi bakması, kişilerarası ilişkilerini idare etmesi, iş aktivitelerini düzenlemesi gibi işlere enerjisini harcayarak öz-düzenlemeyi gerçekleştirmektedir (Cevher ve Buluş, 2006:29; Dinçer, 2008:29; Gürsoy, 2009:51).

Yapılan araştırmalar, benlik saygısı yüksek olan kişilerin kendilerini olan güven duygularının, başarma isteklerinin daha fazla olduğunu, zorluklardan kaçmadıklarını ve daha iyimser olduklarını ortaya koymaktadır (Çağdaş ve Seçer Şahin, 2002:3).

Yaratıcı drama dersinde amaç, olumlu benlik algısına sahip, yaratıcı, üretken, sorgulayan, özgüveni gelişmiş, kendini iyi ifade edebilen, doğru algılayabilen, duygularını tanımlayabilen, Türkçe’yi güzel kullanan olaylar arasında bağlantı kurabilen, gözlem becerisi gelişmiş, toplumsallaşma sürecinde istendik davranışlar gösteren, empati kurabilen, grup arkadaşlarıyla etkileşim sağlayabilen bireyler 
yetiştirmektir (Antepli ve diğ., 2009:462).

Yaratıcı drama, kendilerini değersiz hisseden bireyler için olumlu pekiştirme sağlamak için firsatlar yaratılabilir. Yaratıcı drama sürecinde, karakterin duygu ve isteklerini anlamak ya da tercih ve sonuçları tartışmak için bazı önemli anlar dondurulabilir. Bu, bireylerin kimlik duygularının gelişmesine yardımcı olur. Böylece, bireyler hayali bir olgunun güvenliğine dayanarak kendileri ve başkaları hakkında daha çok şey öğrenebilirler. Sahip oldukları güçlü noktaları, karakterlerini, hoşlandıkları ya da hoşlanmadıkları şeylerin farkına varabilirler (Hendy ve Toon, 2001:63).

McCaslin'e göre eğitimde drama, ilk olarak kişinin benliğinin anlaşılması ve kabul edilmesini sağlayarak, daha sonra çevresindeki diğer kişileri kabul etmeyi ve paylaşımı arttırarak sosyal gelişimi desteklemektedir. Way (1967), eğitimde dramanın olumlu benlik tasarımının oluşmasında, sağlıklı arkadaş ilişkileri geliştirmede ve kişisel özellikler geliştirmede gerekli olduğunu belirtmiştir (Akt. Yayla Ceylan, 2010).

Üniversitelerde 1997 yılından itibaren eğitim fakültelerinin “Okul Öncesi Eğitimi Öğretmenliği” programlarında okul öncesinde yaratıcı drama dersi zorunlu ders olarak yer almıştır (Adıgüzel, 2006a:8). $\mathrm{Bu}$ şekilde gelecek nesilleri yetiştirecek öğretmenlerin, dramayı tanıyan, eğitimde etkili ve verimli bir şekilde kullanan, ayrıca kendini tanıyan ve olumlu benlik tasarımı gelişmiş eğitimciler olmaları sağlanmış olacaktır.

$\mathrm{Bu}$ çalışma, yaratıcı drama dersinin üniversite öğrencilerinin benlik algısı üzerine etkisini incelenmek amacıyla yapılmıştır.

\section{Yöntem}

Bu bölümde araştırmanın örneklemi, veri toplama araçları ve işlem basamakları yer almaktadır.

\section{Örneklem}

Bu çalışmanın örneklemini, Gazi Üniversitesi Mesleki Eğitim Fakültesi Çocuk Gelişimi Eğitimi Öğretmenliği programına devam eden 85 ikinci sınıf öğrencisi oluşturmuştur.

\section{Veri Toplama Aracı}

Veri toplamak amacıyla, Kişisel Bilgi Formu ve Sosyal Karşılaştırma Ölçeği (SKÖ) kullanılmıştır.

Kişisel Bilgi Formu: Kişisel bilgi formunda öğrencilerin yaşı, cinsiyeti, kardeş sayısı, doğum sırası, en uzun yaşadıkları yerleşim merkezi, anne babalarının yaşı ve eğitim düzeyi gibi demografik özelliklerini belirlemek amacıyla hazırlanmış sorular yer almaktadır.

Sosyal Karşılaştırma Ölçeği (SKÖ): Bu ölçek ruhsal sorun belirtileri yüksek olan kişilerin, kendilerini başka insanlarla karşılaştırırken önemli kişilik boyutlarında olumsuz değerlendirme yaptıkları hipotezi ile hazırlanmıştır. Gilbert ve Trent tarafından 5 madde halinde biçimlendirilen ölçek, Şahin ve Şahin'in (1992) yapmış olduğu bir çalışma sonucu bazı maddelerin eklenmesi ile 18 maddelik bir ölçek haline getirilmiştir. 1-6 arası Likert tarzında puanlanan bir ölçektir. Yüksek puanlar olumlu benlik şemasına, 
düşük puanlar ise olumsuz benlik şemasına işaret eder. Ölçeğin orijinalinden elde edilen Cronbach alfa katsayısı a $=.87$ olarak belirtilmektedir. Özelliklerin Beck Depresyon Envanteri ile korelasyonları da $\mathrm{r}=$ -.57 ve $\mathrm{r}=-.77$ arasında değişmektedir. Yukarıda söz edilen ve toplam 540 ortaokul, lise ve üniversite öğrencisi üzerinde yapılan çalışmada da ölçeğin Cronbach alfa güvenilirlik katsayısı 79 olarak bulunmuştur. Ölçeğin bu haliyle depresif belirtileri yüksek ve düşük olan grupları başarılı olarak ayırt edebildiği görülmüştür. Ayrıca ölçeğin BDE ile arasındaki korelasyon -.19 ( $\mathrm{p}<.001)$ olarak bulunmuştur. Şahin ve Şahin (1992)'in bu çalışmasında ölçekten alınan puanlar, örneklem grubu 12-14, 15-17 ve 18 26 olmak üzere üç ayrı yaş grubuna bölünerek karşılaştırılmış ve bu üç ayrı yaş grubu arasında anlamlı bir farklılığın olmadığı görülmüştür (Şahin ve diğ, 2002). Ölçekteki maddeler, 1. Yetersiz - Yeterli 2. Beceriksiz - Becerikli 3. Başarısız - Başarılı 4. Sevilmeyen Biri - Sevilen Biri 5. içedönük - Dışadönük 6. Yalnız - Yalnız Değil 7. Dışta Bırakılmış - Kabul Edilmiş. 8. Sabırsız - Sabırlı 9. Hoşgörüsüz - Hoşgörülü 10. Söylenileni Yapan - inisiyatif Sahibi 11. Korkak Cesur 12. Kendine Güvensiz - Kendine Güvenli 13. Çekingen - Atılgan 14. Dağınık-Düzenli 15. Pasif - Aktif 16. Kararsız - Kararl1 17. Antipatik - Sempatik 18. Boyun Eğici - Hakkını Arayıcı olarak oluşturulmuştur (Sayıner ve diğ, 2007).

\section{İşlem}

Ön test ve son test olarak Sosyal Karş1laştırma Ölçeği, 2008-2009 eğitim öğretim döneminde, Gazi Üniversitesi Mesleki Eğitim Fakültesi Çocuk Gelişimi Eğitimi Öğretmenliği Programında eğitim gören ikinci sınıf öğrencilerine araştırmacılar tarafından sınıf ortamında uygulanmıştır. Yaratıcı drama eğitimi dört ay, haftada dört saat araştırmacılar tarafından yaratıcı drama atölyesinde verilmiştir. Eğitim programının içeriğinde özellikle öğrencilerin kendilerini rahatlıkla ifade edebilmeleri için tanışma, iletişim ve etkileşim etkinlikleriyle başlayarak yaratıcı drama kavramı ve bileşenleri, yaratıcı drama sürecinin yapılandırılması, oyun ve yaratıcı drama, doğaçlama, rol oynama, kendimizi ifade etme yolları, müze ve yaratıcı drama, çocuklukta oyun, okul öncesi çocuklarda algı, öykü ve yaratıcı drama, resimfotoğraf ve yaratıcı drama, maske- kukla ve yaratıcı drama, nesneler- kavramlar ve yaratıcı drama, dans- ritm ve yaratıcı drama, genel değerlendirme, proje yapma ve uygulama konuları yer almaktadır. Ayrıca her hafta ders bitiminde öğrencilerin kendileriyle ilgili farkındalık kazanmaları amacıyla, "Ne düşündük? Ne yaşadık?”, "Kendimi Nerede Görüyorum” ve "Günlük Yaşamla İlişkilendirilme” gibi konularda değerlendirmelere yer verilmiştir. Bir derslik uygulama örneği aşağıda verilmiştir.

Konu: İletişim Benimle Başlar

\section{Isınma-Hazırlık:}

1. Etkinlik: Grup çember olur. Herkes adını söyler ve kendini tanımlayan bir sözcük ilave eder.

2. Etkinlik: Gruptakiler kendi adını bir kağıda akrostij tekniği ile yazar. İsmindeki her harfe kendini tanıtan ve o harfle başlayan bir sözcük yazar ve o kağıtlar toplanır. Kişilere rastgele dağıtılır. Gruptakiler bu sözcüklerden bir cümle oluşturur. Bu cümleler yüksek sesle okunur tanımlamanın kime ait olduğu bulunur.

3. Etkinlik: Grup ritme uygun hareket eder. Lider ritmi durduğunda söylediği yönergeye uygun birbiriyle “merhabalaşması" istenir. Örneğin, ilkokul öğretmeninizle karşılaştınız ona merhaba deyiniz, bölüm 
başkanınıza, tatil dönüşü en sevdiğiniz arkadaşınıza, eve geç kaldınız ailenize, en koktuğunuz dersten geçtiniz ailenize, uygulama yaptığınız okuldaki 5 yaşındaki öğrencinize vb. Aynı kişisiniz söylediğiniz sözcük de aynı ama davranışımız değişiyor neden diye lider gruba sorar ve beyin firtınası yapılır. Daha sonra lider "davranışlarımızı duygu ve düşüncelerimiz" belirliyor diye Mercedes üçgenini açıklar.

4. Etkinlik: Grup ritme uygun hareket eder. İkilinin birbirleriyle yönergeye uygun temas etmeleri sağlanır. Sürekli eşler değişir. Daha sonra sırt sırta eşleştiklerinde yere oturmaları istenir. Kağıt kalem dağıtılır ve şekil çizmeleri istenir. Çizdikleri şekilleri birbirlerine sadece anlatarak çizdirmeleri istenir. Çizilenler karşılaştırılır ve farklılıklar ortaya çıkar. "Anlatabilmek mi -Anlayabilmek mi” daha zor diye tartışılır.

\section{Canlandirma}

5. Etkinlik: Katılımcılar eşleşirler. "İzin isteme" durumu üzerine doğaçlama yapmaları istenir. İkili gruplara farklı roller lider tarafından verilir. Örneğin, öğretmen-öğrenci, öğretmen-müdür, öğrenci öğrenci, ebeveyn öğrenci, öğretmen- öğretmen vb.

\section{Ara Değerlendirme}

6. Etkinlik: Lider tarafından "Durum, Rol, İlişki” bağlantısı açıklanır. Rolümüzü amacımız-StatümüzTutum ve Tavırlarımızın belirlediği gerçek yaşamdan örneklerle açıklanır. Dört-beş kişilik gruplar oluşturmaları istenir. Ortak bir durum yaratılıp ona uygun roller belirlemeleri sağlanır ve canlandırmaları istenir.

\section{Değerlendirme- Tartışma:}

7. Etkinlik: Gruptakiler tekrar akrostij tekniği ile adını yazar. İlk yazdıkları ile karşılaştırmaları sağlanır. Çalışmanın kazanımlarının neler olabileceği grup olarak tartışarak belirlenir.

Örnekleme alınan gruplardan elde edilen veriler, SPSS istatistik programı kullanılarak analiz edilmiştir. Toplanan veriler, incelenen bağımsız değişkenlere göre analiz edilmiş ve bu analizlerde "Wilcoxon İşaretli Sıralar Testi” ve "T-Testi” kullanılmıştır. Yaratıcı darama dersi alan öğrencilerin dersin kendilerine olan katkılarına ilişkin görüşlerinin yüzdelik değerleri ve medyan, minimum, maximum değerleri verilmiştir.

\section{Bulgular ve Yorum}

Örneklemde yer alan öğrencilerin cinsiyetleri, yaş grupları, en uzun yaşadıkları yerleşim merkezine, aile yapısına, kardeş sayısına, anne-baba öğrenim düzeyine ve anne -babanın mesleklerine ait bilgiler Tablo 1- 3 arasında verilmiştir. Deney Öncesi ve Sonrası Sosyal Karşılaştırma Ölçeği Puanlarının Ortalama, Standart Sapma ve Wilcoxon İşaretli Sıralar Testi sonuçları tablo 4'te, Sosyal Karşılaştırma Ölçeği Puanlarının en son bitirdiği okul türüne göre t-testi sonuçları ise tablo 5'te sunulmuştur. 
Tablo 1. Öğrencilerin Demografik Özelliklerine Göre Dă̆ılımı

\begin{tabular}{|c|c|c|}
\hline & $\mathbf{n}$ & $\%$ \\
\hline \multicolumn{3}{|l|}{ Cinsiyet } \\
\hline $\mathrm{K}_{1 \mathrm{z}}$ & 84 & 98.8 \\
\hline Erkek & 1 & 1.2 \\
\hline \multicolumn{3}{|l|}{ Öğrenci Yaşı } \\
\hline $18-20$ yaş & 50 & 58.8 \\
\hline $21-23$ yaş & 27 & 31.8 \\
\hline 24-26 yaş & 8 & 9.4 \\
\hline \multicolumn{3}{|l|}{ En uzun Yaşadığı Yerleşim Merkezi } \\
\hline Şehir Merkezi & 41 & 48.2 \\
\hline İlçe Merkezi & 28 & 32.9 \\
\hline Kasaba & 11 & 12.9 \\
\hline Köy & 5 & 5.9 \\
\hline \multicolumn{3}{|l|}{ Bitirdiği Okul } \\
\hline Meslek Lisesi & 63 & 74.1 \\
\hline $\begin{array}{l}\text { Diğer (Süper Lise, Normal Lise, Anadolu } \\
\text { Lisesi, Çok Programlı Lise) }\end{array}$ & 22 & 25.9 \\
\hline \multicolumn{3}{|l|}{ Aile Yapısı } \\
\hline Çekirdek Aile & 67 & 78.8 \\
\hline Geniş & 18 & 21.2 \\
\hline \multicolumn{3}{|l|}{ Kardeş Sayısı } \\
\hline Tek çocuk & 15 & 17.6 \\
\hline İki kardeş & 25 & 29.4 \\
\hline Üç kardeş & 21 & 24.7 \\
\hline Dört kardeş ve üzeri & 24 & 28.3 \\
\hline Toplam & 85 & 100.0 \\
\hline
\end{tabular}

Tablo 1 incelendiğinde, araştırmaya alınan öğrencilerin \% 98.8'inin kız, \% 1.2'sinin erkek olduğu, öğrencilerin yaş gruplarına göre dağılımlarına bakıldığında \% 58.8'ini 18-20 yaş arası, 31.8'ini 21-23 yaş arası, 9.4'ünü 24-26 yaş arası olduğu görülmektedir. Öğrencilerin en uzun yaşadıkları yerleşim merkezine göre dağılımlarına bakıldığında, birinci sırayı şehir merkezinde yaşayanlar (\% 48.2), ikinci sırayı ilçe merkezinde yaşayanlar (\% 32.9), üçüncü sırayı kasabada yaşayanlar (\% 12.9), dördüncü sırayı ise köyde yaşayanlar (\% 5.9) oluşturmaktadır. Öğrencilerin \% 74.1'i Meslek Lisesi mezunu, \% 25.9'u ise diğer (Süper Lise, Normal Lise, Anadolu Lisesi, Çok Programlı Lise) liselerden mezundurlar. Öğrencilerin \% 78.8'i çekirdek aileden, \% 21.2'si ise geniş aileden gelmektedir. Öğrencilerin \% 17.6'sının tek çocuk, \% 29.4'ünün iki kardeşe , \% 24.7'ünün üç kardeşe, \% 28.3'ünün dört kardeş ve üzerine sahip olduğu görülmektedir. 
Tablo 2. Öğrencilerin Annelerinin ve Babalarının Öğrenim Durumlarına Göre Dă̆ılımı

\begin{tabular}{|c|c|c|c|c|}
\hline \multirow{3}{*}{ Öğrenim Durumu } & \multicolumn{4}{|c|}{ Deney } \\
\hline & \multicolumn{2}{|c|}{ Anne } & \multicolumn{2}{|c|}{ Baba } \\
\hline & $\mathrm{n}$ & $\%$ & $\mathrm{n}$ & $\%$ \\
\hline Okur Yazar & 14 & 16.5 & 2 & 2.4 \\
\hline İlkokul Mezunu & 37 & 43.5 & 34 & 40.0 \\
\hline Ortaokul Mezunu & 21 & 24.7 & 18 & 21.2 \\
\hline Lise Mezunu & 8 & 9.4 & 16 & 18.8 \\
\hline $\begin{array}{l}\text { Üniversite ya da } \\
\text { Yüksekokul Mezunu }\end{array}$ & 4 & 4.7 & 14 & 16.5 \\
\hline Toplam & 84 & 100.0 & 84 & 100.0 \\
\hline
\end{tabular}

Tablo 2'de araştırmaya katılan öğrencilerin annelerinin öğrenim durumlarına göre dağılımları incelendiğinde, \% 16.5'inin okur-yazar, \% 43.5'inin ilkokul mezunu, \% 24.7'sinin ortaokul mezunu, \% 9.4'ünün lise mezunu, \% 4.7'sinin üniversite ve yüksek okul mezunu olduğu, babalarının ise, \% 2.4'sünün okur-yazar, \% 40.0'1nın ilkokul mezunu, \% 21.2'sinin ortaokul mezunu, \% 18.8'inin lise mezunu, \%16.5'inin üniversite ve yüksek okul mezunu olduğu bulunmuştur.

Tablo 3. Öğrencilerin Annelerinin ve Babalarının Mesleklerine Göre Dă̆ılımı

\begin{tabular}{lcrcc}
\hline \multirow{2}{*}{ Mesleği } & \multicolumn{3}{c}{ Deney } \\
\hline \multirow{2}{*}{ İçi } & $\mathrm{n}$ & $\%$ & $\mathrm{n}$ & $\%$ \\
Memur & 9 & 10.6 & 17 & 20.0 \\
Emekli & 2 & 2.4 & 17 & 20.0 \\
Serbest Meslek & 5 & 5.9 & 21 & 24.7 \\
Ev Hanımı & 1 & 1.2 & 30 & 35.3 \\
Toplam & 68 & 80.0 & - & - \\
\hline
\end{tabular}

Tablo 3'te araştırmaya katılan öğrencilerin annelerinin mesleğine göre dağılımları incelendiğinde, \% 10.6's1 işçi, \% 2.4'ü memur, \% 5.9'u emekli, \% 1.2'si serbest meslek, \% 80.0'1 ev hanımıdır. Öğrencilerin babalarının ise, \% 20.0' sinin işçi, \% 20.0'sinin memur, \% 24.7'sinin emekli, \% 35.3'ünün serbest meslek olduğu görülmektedir. 
Araştırmaya katılan öğrencilerin, deney öncesi ve sonrası benlik algılarının anlamlı bir farklılık gösterip göstermediğine ilişkin Wilcoxon işaretli sıralar testi sonuçları tablo 4’te verilmiştir.

Tablo 4. Sosyal Karşılaştırma Ölçeği Ön test ve Son Test Ortalama Puanların t-Testi Sonuçları

\begin{tabular}{lcccccc}
\hline & $\mathrm{N}$ & $\overline{\mathrm{X}}$ & $\mathrm{S}$ & $\mathrm{sd}$ & $\mathrm{t}$ & $\mathrm{p}$ \\
\hline Ön Test & 85 & 83.08 & 12.31 & & & \\
Son Test & 85 & 93.43 & 6.47 & & & \\
& & & & & & \\
\hline$* \mathrm{p}<.001$ & & & & & &
\end{tabular}

Tablo 4’te araştırmaya katılan öğrencilerin yaratıcı drama eğitimi sonrasında benlik algılarında anlamlı bir artış olduğu bulunmuştur [ $\left.\mathrm{t}_{(84)}=-12.04, \mathrm{p}<.001\right]$. Öğrencilerin eğitim öncesi benlik algıları puan ortalamaları $X=83.08$ iken, yaratıcı drama eğitimi sonrasında $X=93.43$ 'e yükselmiştir. Bu sonuçlara göre, düzenlenen yaratıcı drama eğitiminin öğrencilerin benlik algısı üzerinde olumlu yönde etkisi olduğu söylenebilir.

Fleming, Merrell ve Tymms (2004), dramanın ilkokul çocuklarının davranışlarına ve benlik algılarına etkisini inceledikleri araştırma sonucunda, deney grubu öğrencilerin kontrol grubundaki öğrencilerden benlik olguları daha olumlu yönde farklılıklar göstermiştir.

Güleç (2005), yaptığ çalışmada yaratıcı dramanın olumlu benlik tasarımını geliştirdiğini bulmuştur. Taşkıran (2005), ilköğretim dördüncü sınıf öğrencilerinin benlik kavramları üzerinde dramanın olumlu etkisi olduğunu saptamıştır.

Ünal Erhan (2000) ilköğretim üçüncü sınıf öğrencilerinin benlik kavramları üzerinde eğitimde dramanın etkisini incelemek amacıyla yaptığı araştırma sonucunda, eğitimde dramanın benlik kavramı gelişimi üzerinde olumlu etkisi olduğunu bulmuştur.

Yapılan araştırmalarda, yaratıcı drama eğitiminin benlik algısı üzerinde olumlu etkisi olduğu görülmektedir. Bu sonuç, araştırma bulgularını destekler niteliktedir.

Tablo 5. Sosyal Karşılaştırma Ölçeği Puanlarının En Son Bitirdiği Okul Türüne Göre T-Testi Sonuçları

\begin{tabular}{lccccc}
\hline \multirow{2}{*}{ En Son Bitirdiği Okul } & \multicolumn{2}{c}{ Ön Test } & \multicolumn{2}{c}{ Son Test } \\
Meslek Lisesi & 63 & 82.55 & 10.60 & 93.44 & 6.26 \\
$\begin{array}{l}\text { Diğer (Süper Lise, Normal } \\
\begin{array}{l}\text { Lise, Anadolu Lisesi, Çok } \\
\text { programlı Lise) }\end{array}\end{array}$ & 22 & 84.59 & 16.47 & 93.40 & 7.18 \\
& & & & & \\
\hline T -Testi & & $\mathrm{t}=-.547$ & $\mathrm{t}=.021$ \\
$\mathrm{p}=.592$ & $\mathrm{p}=.984$ \\
\hline
\end{tabular}


Tablo 5'te görüldüğü gibi yaratıcı drama eğitimi alan öğrencilerin en son bitirdiği okul türüne göre ön test-son test puanları arasında anlamlı bir fark yoktur ( $p>.005)$. Öğrencilerin ön test-son test puanlarının daha önce bitirdikleri okul türünden anlamlı ölçüde etkilenmediği görülmüştür. Bitirdiği okul türünün etkisi olmaksızın, verilen eğitim sonrası ortalama puanlarında artış görülmüştür. Bu sonuca bağlı olarak, yaratıcı drama eğitiminin tüm öğrencilere aynı derecede katkılar sağlayarak eşit firsatlar sunduğunu söyleyebiliriz.

\section{Sonuç ve Öneriler}

Araştırma sonuçlarına göre, yaratıcı drama eğitimi alan öğrencilerin Sosyal Karşılaştırma Ölçeği’nden aldıkları deney öncesi ve sonrası puanları arasında anlamlı bir fark olduğunu göstermektedir ( $<<.000)$. Yaratıcı drama eğitimi alan öğrencilerin en son bitirdiği okul türüne göre ön test-son test puanları arasında ise anlamlı bir fark olmadığı bulunmuştur ( $\mathrm{p}>$.005). Bu sonuçlara göre, yaratıcı drama eğitim programının öğrencilerin bitirdikleri okul türüne bağlı olmaksızın, öğrencilerin benlik algısını olumlu yönde etkilediği düşünülebilir.

Verilen yaratıcı drama dersi, çocuk gelişimi eğitimi öğretmen adaylarının duygu ve düşüncelerinin, içindeki enerjinin, gücün farkına varmasını sağlayarak toplumsal yaşam içersinde daha aktif ve verimli bir rol üstlenmesine, kişilerarası ilişkilerinin güçlenmesini, kendini olduğu gibi kabul etmesini, kendine güvenmesini ve ifade etmesini sağlayacaktır. Böylece yaratıcı drama olumlu benlik duygusunun gelişimine katkı sağlayacaktır. Olumlu benlik duygusu gelişmiş bir öğretmen adayı, eğitim verecekleri çocuklara da neler kazandırabileceklerinin farkına vararak, çocukların kendilerini ifade etmelerini, işbirliği içerinde olmalarını, sorumlulukları paylaşmalarını ve yaratıcılıklarını geliştirmeleri için firsatlar yaratacaktır.

Bu sonuçlar doğrultusunda, aşağıdaki öneriler verilebilir,

- Olumlu benlik algısı gelişmiş öğretmenler yetiştirmek isteniyorsa, yaratıcı drama dersinin tüm öğretmenlik programlarında zorunlu ders olarak yer alması ya da isteyen öğrencilerin seçmeli ders olarak alabilmesi sağlanabilir.

- Yaratıcı drama dersinin öğrencilerin kişisel gelişimleri üzerinde daha fazla katkı sağlaması açısından ders saatleri de arttırılabilir.

- Öğrencilerin olumsuz benlik algılarının hangi yönde olduğu incelenerek, bu konularda Psikodrama alanında uzmanlardan destek alarak kurs ve atölyeye vb. etkinliklere yönlendirilebilir. 


\section{Kaynaklar}

Adıgüzel, Ö. (2006a). Yaratıcı drama derslerine (okulöncesinde drama ve ilköğretimde drama) ilişkin tutum ölçeği geliştirilmesi. Yaratıcı Drama Dergisi, 1(2),7-11.

Adıgüzel, Ö. (2006b). Yaşantılara dayalı öğrenme, yaratıcı drama ve süreçsel drama ilişkileri, Yaratıcı Drama Dergisi, 1(1).

Antepli, S., Dizdaroğlu, B., Öztepe, B. (2009). İlköğretimde yaratıcı drama ve öz değerlendirme, Ĕ̆itimde Yeni Yönelimler-V Öğrenmenin Doğası ve Değerlendirme Sempozyumu, Özel Tevfik Fikret Okulları, İzmir, 18 Nisan.

Can Yaşar, M. ve Ömeroğlu, E. (2005). Drama dersi alan kız meslek lisesi son sınıf öğrencilerinin drama dersine ilişkin görüşlerinin incelenmesi, Eğitimde Yeni Yönelimler II, Eğitimde Oyun Sempozyumu, Özel Tevfik Fikret Okulları, Ankara, 14 Mayıs,

Cevher, F. N. ve Buluş, M. (2006). Okul öncesi eğitim kurumlarına devam eden 5-6 yaş çocuklarında akademik benlik saygısı. Dokuz Eylül Üniversitesi Buca Eğitim Fakültesi Dergisi, 20, 28-30.

Çağdaş, A. ve Seçer Şahin, Z. (2002). Çocuk ve Ergende Sosyal ve Ahlak Gelişimi. R. Arı (Ed.). Ankara: Nobel Yayın Dağıtım.

Dinçer, F. (2008). Hemşirelikve ebelikögrencilerinin benliksaygısı ve atılganlık düzeyleri. Yayınlanmamış Yüksek Lisans Tezi, Adana: Çukurova Üniversitesi, Sağlık Bilimleri Enstitüsü Anabilim Dalı.

Fleming, M., Merrell, C. and Tymms, P. (2004). The impact of drama on pupils' language, mathematics, and attitude in two primary schools. Research in Drama Education. 9(2):177-197.

Güven, İ. (2006). Okul öncesinde dramadan yararlanma ilkeleri, çocukta yaratıcıllk ve drama, A. Öztürk (Ed.) (4. Bask1). Eskişehir: Anadolu Üniversitesi.

Güleç, H. (2005), Dramanın benlik kavramı üzerine etkisi. 2. Uluslar Arası Çocuk ve İletişim Kongresi, İstanbul Üniversitesi İletişim Fakültesi, İstanbul, 4-6 Nisan.

Gürsoy, R. C. (2009). Okul öncesi öğretmenlerinin benlik saygllarının ögretmenlik tutumlarına etkisinin incelenmesi. Yayınlanmamış Yüksek Lisans Tezi, İstanbul: Marmara Üniversitesi.

Hendy, L and Toon, L. (2001). Supporting drama and imaginative play in the early years. Buchkingham. Philadelphia: Open University Press.

Kara, Y. ve Çam, F. (2007). Yaratıcı drama yönteminin bazı sosyal becerilerin kazandırılmasına etkisi. Hacettepe Üniversitesi Ĕ̈itim Fakültesi Dergisi, 32, 145-155.

Min Lin, S. (1999). The effect of creative drama on story comprehension for children in tawan. Ph.D Thesis, USA: Arizona State University.

San, İ. (2002). Eğitimde yaratıcı drama. Yaratıcı drama. H.Ö.Adıgüzel (Ed.),(1. Baskı) Ankara: Naturel Yayınc1lik. 
Sayıner, B., Savaşan, E., Sözen, D., Köknel, Ö. (2007). Yükseköğretim gençliğinin benlik algısının çeşitli değişkenlere göre incelenmesi: İstanbul ticaret üniversitesi örneği, Ístanbul Ticaret Üniversitesi Sosyal Bilimler Dergisi, 6 (11),253-265.

Şahin, N. H., Durak Batıün, A., Uğurtaş, S. (2002). Kısa Semptom Envanteri (KSE): ergenler için kullanımının geçerlik, güvenilirlik ve faktör yapısı, Türk Psikiyatri Dergisi, 13(2): 125-135.

Taşkıran, S. (2005). Drama yöntemi ile ilkögrretim dördüncü sınıf sosyal bilgiler dersinin işlenişinin ögrenme ve öğrencilerin benlik kavramına etkisi yönünden değerlendirilmesi. Konya: Yayınlanmamış Yüksek Lisans Tezi: Selçuk Üniversitesi.

Uşaklı, H. (2006). Drama temelli grup rehberliğinin ilköğretim V. sınıf öğrencilerinin arkadaşlık ilişkileri, atılganlık düzeyi ve benlik-saygısına etkisi. Yayınlanmamış Doktora Tezi. İzmir: Dokuz Eylül Üniversitesi.

Ünal Erhan, T. (2000). İlköğretimde hayat bilgisi dersinin drama ile verilmesinin dersin öğrenilmesine ve çocukların benlik kavramlarına etkisinin incelenmesi. Ankara: Yayınlanmamış Yüksek Lisans Tezi, Hacettepe Üniversitesi.

Yayla Ceylan, Ş. (2010). Okul Öncesi Eğitimde Drama “Sosyal-Duygusal Gelişim” E. Ömeroğlu, (Ed.) Ankara: Mavi Yunus Karaca Eğitim Yayınları. 


\section{Summary}

\section{The Effect of Creative Drama Course on the Sense of Self of University Students}

\author{
Serap ANTEPL' $\dot{\mathbf{I}}^{1}$
}

\author{
Şehnaz CEYLAN²
}

\section{Introduction}

Beside being a new formation compared to traditional methods in education and teaching, creative drama bares a number of positive things in terms of its impact and application. An individual in an education system depending on memorizing cannot find an opportunity to seek for and share information. In this sense, creative drama is a strong alternative for a subject centred, memorizing based and constructed education. Therefore, creative drama is a significant method that should be used in every stage of education frequently. In addition, the most important feature of creative drama as an effective way of learning is that it is combined with cognitive, affective, social and kinaesthetic skills. In education, being able to use sense organs by doing and experiencing is an important principle. Change of information, skills and behaviour through creative drama is of great importance in terms of the fact that it has an impact on the perspective of individual over life. And this increases permanence in learning (Güven, 2006:141; Adıgüzel, 2006a:8; Can Yaşar and Ömeroğlu, 2005:168). Researches point out that people with a high sense of self have a higher self esteem, have a will to succeed, do not avoid challenges and are more optimistic (Çağdaş and SeçerŞahin, 2002:3). The purpose in the course of creative drama is to train creative, productive individuals with a positive sense of self and higher self esteem, being able to express himself, perceive the truth, define senses, use Turkish well, make a connection between the events, with an improved observation skill, showing desired behaviour in the process of socialization, being able to develop empathy and interact with the friends in the group (Antepli et al., 2009:462). The course of drama has taken place in the programs of "Preschool Education Teaching" in the faculties of education at universities as a compulsory course from 1997 onwards (Adigüzel, 2006a:8). In that way, teachers that will train future generations will be given an opportunity to become educators who know drama, use it in an effective and productive way, also know himself and have an improved self design.

This study was carried out to examine the effect of sense of self of university students on the course of creative drama.

$1 \quad$ Child Development and Education Specialist-Drama Leader, E-mail: serapmiya@hotmail.com

2 Assit. Prof. Dr., Karabük Ünivesity Facult of Literature, Department of Education Sciences, E-mail: sehnaz@gmail.com 


\section{Method}

In this part, the sampling of the research, data collection instruments and process stages take place.

\section{Sample}

The sampling of the study consists of 85 second year students attending Gazi University, Faculty of Vocational Education, Child Development Education teaching program.

\section{Data Collection Instrument}

In order to collect data, Personal Information Form and Social Comparison Scale (SCS) have been used. Personal Information Form:In the personal information form questions are given that were asked to determine features such as the age of students, their gender, number of siblings, birth rank, the location they lived the longest, the age of parents and education level.

Social Comparison Scale (SCS):This scale has been prepared with a hypothesis where people with high symptoms of psychological problems could make negative evaluations at significant levels of personality while comparing themselves with others. Prepared as 5 items by Gilbert and Trent, the scale has been added some more items by Şahin and Şahin (1992) and became a scale of 18 items. It is a Likert type scale scored as 1-6. Higher scores indicate positive self scheme while low scores indicate negative self schemes.

\section{Procedure}

As a pre-test and post test, Social Comparison Scale has been applied to second year students attending to Gazi University, Faculty of Vocational Education, Child Development Education teaching program by the researchers in the academic year of 2008-2009. Creative drama education had been given by the researchers for four months as four hours a week in the drama atelier. The collected data have been analysed depending on the independent variables examined and "Wilcoxon Marked Rank Test" and "t-test" has been used in these analyses. The percentage, median, minimum and maximum values of the views of students taking the course of creative drama over the contribution of the course to them were given.

\section{Conclusion and Suggestions}

According to the results of the research, a significant difference has been found between the pre-test and post test scores student obtained in the Social Comparison Scale $(\mathrm{p}<.000)$. However, no significant difference has been found between the pre and post test scores depending on the latest school that the students took the course of creative drama education graduated ( $p>005)$. According to these results, it is likely to think that creative drama education program has a positive sense of self on students regardless of the school they graduated.

Depending on these results, the following could be recommended;

- If we are to train teachers with improved positive sense of self, the course of creative drama could be given place as a compulsory course and it could also be given as a selective course. 
- The teaching hours could be increased in order that creative drama course can make more contribution to the personal development of students.

- Towards which direction the students' negative sense of self is could be investigated and experts in the field of psychodrama could be asked for a support in these issues and the students could be led to courses and ateliers etc. 